\title{
Postharvest Disease Development on Southern Highbush Blueberry Fruit in Relation to Berry Flesh Type and Harvest Method
}

L. K. Mehra, Department of Plant Pathology, University of Georgia, Athens 30602; D. D. MacLean, Department of Horticulture, University of Georgia, Tifton 31793; and A. T. Savelle and H. Scherm, Department of Plant Pathology, University of Georgia, Athens 30602

\begin{abstract}
Mehra, L. K., MacLean, D. D., Savelle, A. T., and Scherm, H. 2013. Postharvest disease development on southern highbush blueberry fruit in relation to berry flesh type and harvest method. Plant Dis. 97:213-221.

Postharvest decay, incited by various fungal pathogens, is a major concern in most blueberry production areas of the United States. Because the risk of infection is increased by fruit bruising, which in turn is increased by machine-harvesting, it has been difficult to harvest fruit from the early-maturing but soft-textured southern highbush blueberries (SHB) mechanically for the fresh market. This could change fundamentally with the recent development of SHB genotypes with crisp-textured ("crispy") berries, i.e., fruit with qualitatively firmer flesh and/or more resistant skin. Four replicate row sections of two or three SHB genotypes having crispy fruit and three with conventional fruit were either hand- or machine-harvested at a commercial blueberry farm in northern Florida in April 2009 and May 2010. Harvested fruit were sorted, packed, and placed in cold storage $\left(2^{\circ} \mathrm{C}\right)$ for up to 3 weeks. Average counts of aerobic bacteria, total yeasts and molds, coliforms, and Escherichia coli on fruit samples before the cold storage period were below commercial tolerance levels in most cases. In both years, natural disease incidence after cold storage was lowest

for hand-harvested crispy fruit and highest for machine-harvested conventional fruit. Interestingly, machine-harvested crispy fruit had the same or lower disease incidence as hand-harvested conventional fruit. Across all treatments, natural postharvest disease incidence was inversely related to fruit firmness, with firmness values $>220 \mathrm{~g} / \mathrm{mm}$ associated with low disease. In separate experiments, samples from the 0-day cold storage period were inoculated at the stem end with Alternaria alternata, Botrytis cinerea, or Colletotrichum acutatum, and disease incidence was assessed after 7 days in a cold room followed by 60 to $72 \mathrm{~h}$ at room temperature. In response to artificial inoculation, less disease developed on crispy berries. No significant effect of harvest method was observed, except for A. alternata inoculation in 2009, when hand-harvested fruit developed a lower level of disease than machine-harvested fruit. Taken together, this study suggests that mechanical harvesting of SHB cultivars with crisp-textured berries is feasible from a postharvest pathology perspective.
\end{abstract}

The United States ranks first in the production of blueberries worldwide, supplying $166,786 \mathrm{t}$ in 2009 with a farm gate value of $\$ 507$ million (1). Georgia ranks second nationally with $16 \%$ of the total cultivated blueberry acreage and fourth to fifth in total blueberry fruit production. With a farm gate value of $\$ 102$ million $(1,6)$, blueberry is the state's most important fruit crop. Currently, $>80 \%$ of the cultivated acreage is devoted to rabbiteye blueberries (Vaccinium virgatum $=V$. ashei), with the remainder planted to southern highbush blueberries (SHB) (V. corymbosum interspecific hybrids). Notwithstanding their lower acreage, one-third of the blueberry farm gate value in Georgia in 2009 resulted from sales of southern highbush blueberry fruit (5).

SHB cultivars are developed through interspecific breeding of northern highbush blueberries ( $V$. corymbosum) with native southern species such as $V$. darrowii (22). These cultivars have low chilling requirements and are grown successfully in areas with sandy soils naturally high in organic matter, in sandy soils enriched with pine bark, or in high-density culture on pine bark beds $(13,20)$. SHB acreage in Georgia has increased considerably since the mid-1990s because their fruit ripen earlier than those of rabbiteye cultivars, meeting demand for blueberries in the high-price

\section{Corresponding author: H. Scherm, E-mail: scherm@uga.edu}

Current address of L. K. Mehra: Department of Plant Pathology, North Carolina State University, Raleigh 27695.

Current address of D. D. MacLean: AgroFresh, Inc., Davis, CA 95618.

Accepted for publication 22 August 2012.

http://dx.doi.org/10.1094/PDIS-03-12-0307-RE

(C) 2013 The American Phytopathological Society market window between early spring imports from South America and early summer domestic fruit production from northern highbush blueberries in North Carolina and New Jersey $(13,44)$.

Blueberries can be either hand- or machine-harvested. Hand-harvesting is labor intensive $(1,500 \mathrm{~h} / \mathrm{ha})(7)$, with a cost of $\$ 1.00$ to $\$ 1.70 / \mathrm{kg}$ in southern production areas (43), and is mostly used to achieve high fruit quality for fruit intended for the fresh market (36). Machine-harvesting is labor efficient (25 h/ha) (39), with a cost of $\$ 0.26$ to $0.40 / \mathrm{kg}$ (43), and is usually done later in the season for rabbiteye cultivars when fruit prices are lower and handharvesting becomes uneconomical (36). However, machine-harvesting often results in internal bruising and loss of firmness to the fruit, which in turn leads to decreased shelf life and increased risk of postharvest decay $(31,36)$. As a result, much of the machineharvested fruit is utilized in the processed market, where they receive a lower price $(\sim \$ 1.00 / \mathrm{kg})$ than blueberries sold fresh $(\sim 4.30 / \mathrm{kg})(1)$. Mechanical harvesting systems currently used for the later maturing and lower value rabbiteye fruit are generally not capable of delivering SHB fruit of sufficient quality and shelf life for the fresh market $(15,46)$, especially in production areas such as Florida and Georgia where hot temperatures prevail during the harvest period. As a result, nearly the entire SHB acreage in Georgia is hand-harvested, although interest in mechanical harvesting is increasing rapidly (35).

Berry firmness is a key attribute required for fruit to be machineharvested successfully (35). Currently, fruit of SHB cultivars typically grown in Georgia, such as Star (24) or Emerald, have lower firmness than those of rabbiteye cultivars and are generally not suitable for machine-harvesting. Other examples of cultivars with the conventional SHB fruit type are Scintilla (27) and Primadonna (28). Recently, the University of Florida blueberry breeding program has developed novel crisp-textured ("crispy") SHB cultivars (37), which include Bluecrisp (25), Sweetcrisp (29), and Farthing (26). Although the genetic and anatomical basis of this trait have 
yet to be elucidated in detail, these cultivars have firmer berries and/or a more resistant skin, reduced bruising levels (53), and better storage shelf life than conventional SHB cultivars owing to the springiness of their skin and the increased force needed to rupture the skin (37). These attributes may allow for machine-harvest with reduced bruising, thereby increasing fruit quality and decreasing the risk of postharvest fungal decay.

There is a considerable body of literature describing postharvest rot for northern highbush and rabbiteye blueberries, on which Colletotrichum spp. (causing ripe rot), Alternaria tenuissima and other Alternaria spp. (causing Alternaria fruit rot), and Botrytis cinerea (causing gray mold) are the most commonly reported postharvest decay pathogens $(8,12,32,33,45,46)$. Other fungal genera capable of causing postharvest disease on blueberry fruit, some as opportunistic pathogens, are Aspergillus, Aureobasidium, Catenophora, Cladosporium, Epicoccum, Fusarium, Penicillium, Pestalotiopsis, and Rhizopus $(4,9,48)$. In contrast, there are relatively few reports on postharvest fruit decay of SHB specifically, although it is generally accepted that SHB cultivars are more susceptible to postharvest decay than rabbiteye cultivars $(34,38)$. The main decay-causing organisms on SHB varied by region, with Colletotrichum and Botrytis of greatest importance in Louisiana (23); B. cinerea in Florida (18); and Colletotrichum, Botrytis, and Alternaria species in Spain (4). In general, the incidence of postharvest decay may be exacerbated by machine-harvesting, storage at high temperatures, infestation of handling surfaces, wetness of the stem scar, or presence of moisture $(10,16,31)$.

In addition to attack by postharvest pathogens, blueberries may be subject to microbial contamination during the growing season as well as during harvesting and processing (48). Whereas rigid microbial safety standards are currently in place for processed blueberry products, contamination of fresh market berries is also a concern (41). The use of mechanical harvesting could either decrease microbial contamination because there is less handling of fruit by workers, or increase contamination risk through creation of microbial attachment sites associated with fruit bruising, cracking, and tearing of stems. Hence, it is important to assess microbiological loads on hand- versus machine-harvested fruit of both conventional and the new crisp-textured SHB cultivars.

Based on the above considerations, the objectives of this study were to compare conventional and crisp-textured SHB genotypes after hand- and machine-harvest in relation to microbial contamination on fruit at harvest and subsequent postharvest disease development in cold storage. In addition, fungal organisms associated with postharvest decay were identified.

\section{Materials and Methods}

Study site and cultivars. The study was conducted on a blueberry farm near Waldo, FL, where numerous recent cultivar releases and advanced selections from the University of Florida blueberry breeding program are grown on a commercial scale. The following SHB genotypes having berries with conventional flesh type were included in the study: Primadonna, Scintilla, and Star in 2009; and Scintilla, Star, and FL 01-248 in 2010. Their crisp-textured counterparts were Farthing, Sweetcrisp, and FL 98-325 in 2009; and Farthing and Sweetcrisp in 2010. Plants were between 2 and 5 years old and measured between 1.0 and $2.0 \mathrm{~m}$ in height. Plant spacing was $0.75 \mathrm{~m}$ within rows and $3.5 \mathrm{~m}$ across rows. Crop management followed standard commercial practice (19), which included routine fungicide applications during bloom and fruit development but not at the preharvest stage.

Hand- and machine-harvest. Harvesting experiments were conducted between 24 and 26 April 2009 and 7 and 8 May 2010; the 2010 harvest was unusually late due to below-average winter and spring temperatures. All genotypes were harvested at least once by a commercial hand-harvesting crew prior to the experimental harvest, ensuring that ripe fruit from the different cultivars or selections were at similar maturity levels. Experimental handand machine-harvest was conducted in four replicate row sections per genotype, each containing 13 to 50 bushes, depending on over- all row length in the field. The experimental design was a split-plot with genotype as the main-plot and harvest method as the subplot.

Fruit were either hand-picked into 3.8-liter buckets or harvested by machine. The mechanical harvester used was a self-propelled Korvan 8000 (Oxbo International, Lynden, WA), except for cultivars Star and Farthing in 2010, which were harvested with a tractor-pulled Korvan 930 (Oxbo International). Both harvester models utilize the same fruit detachment mechanism (rotary and oscillating action of beating rods) and differ primarily in their size. The harvesters were operated at a ground speed of 1.1 to $1.6 \mathrm{~km} / \mathrm{h}$ with the rotor set at 640 to $690 / \mathrm{min}$, and the counterweights adjusted according to the width of the bush; these parameters were optimized for each cultivar with the aid of a technician provided by the manufacturer. Fruit harvested by the mechanical harvester were collected into standard blueberry lugs $(60 \times 40 \times 17 \mathrm{~cm})$. Handharvested fruit also were transferred from picking buckets into lugs.

Harvested fruit were precooled and stored temporarily (for 1 to 3 days) at $15^{\circ} \mathrm{C}$ in a mobile field cooler consisting of an insulated box trailer equipped with an evaporative cooler powered by a diesel engine. The same cooler was used to transport the fruit to a packingline at the University of Georgia (UGA) Blueberry Research Farm in Alapaha, GA, where they were sorted and packed into 550-ml (1 pint) plastic clamshells. The packingline included a lift belt, an air blower to remove leaves and twigs, a tilted belt to remove green clusters and heavily damaged fruit, an inspection table where fruit were graded manually for size and color, and a filler to feed fruit into the clamshells. Packingline equipment was not surface-disinfested between fruit samples belonging to different treatment groups. Clamshells containing fruit were placed into cold storage $\left(2^{\circ} \mathrm{C}\right)$ at the UGA Vidalia Onion Research Lab in Tifton, GA.

Fruit surface contaminants. Microbial load on the fruit surface was assessed on fruit samples after they had been sorted and packed into clamshells but before they were placed into cold storage. Due to logistical constraints in conducting the time-sensitive microbial assays, a subsample of four genotypes was used in both years: Primadonna and Scintilla (both with conventional flesh) and FL 98-325 and Sweetcrisp (both with crispy flesh) in 2009; and Star and Scintilla (conventional) and Farthing and Sweetcrisp (crispy) in 2010. For each genotype and replicate, one 50-g fruit sample (40 to 50 berries) was placed in a sterile $500-\mathrm{ml}$ flask con-

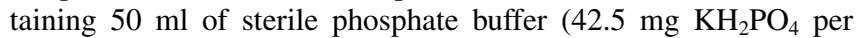
liter; $\mathrm{pH}$ 7.2). The mouth of the flask was wrapped with aluminum foil and Parafilm, and the flask was agitated on a wrist action shaker at medium speed for $15 \mathrm{~min}$. Aliquots of the wash buffer and of 1:20 or 1:100 dilutions were plated in triplicate onto plate count agar (PCA), dichloran rose bengal chloramphenicol (DRBC) agar, and 3M Petrifilms (3M Microbiology, St. Paul, MN) for enumeration of aerobic bacteria, total yeasts and molds, and Escherichia coli and coliforms, respectively. PCA and DRBC agar dishes were incubated at room temperature $\left(23\right.$ to $\left.25^{\circ} \mathrm{C}\right)$ and colonies counted after 3 and 5 days, respectively. Petrifilms were incubated at $35^{\circ} \mathrm{C}$ and evaluated after 2 days. Colony-forming units (CFU) per gram of fruit were $\log (\mathrm{CFU}+1)$ transformed and subjected to split-plot analysis of variance with genotype (or flesh type group) as the main-plot and harvest method as the subplot using PROC GLIMMIX in SAS v. 9.2 (SAS Institute, Cary, NC).

Natural postharvest disease incidence. Postharvest disease development was assessed on a subsample of four genotypes each year, i.e., Scintilla and Star (conventional flesh) and Farthing and Sweetcrisp (crispy flesh). These cultivars matched best in plant size and maturity levels and were consistently available for testing in both years. Clamshells were removed from cold storage after 0 , 7,14 , and 21 days, at which time firmness was measured on a subsample of 50 berries per genotype and replicate using a FirmTech II instrument (BioWorks, Wamego, KS). Fruit removed from cold storage were maintained at 23 to $25^{\circ} \mathrm{C}$ in clamshells for an additional 4 days, at which time the number of fruit with symptoms or signs of postharvest decay was counted from a total of 50 to 100 
fruit per replicate. Percent disease incidence was arcsine squareroot transformed and subjected to split-split-plot analysis of variance with genotype (or flesh type group) as the main-plot, harvest method as the subplot, and cold storage time as the sub-sub-plot using PROC GLIMMIX. Furthermore, postharvest disease incidence was regressed against fruit firmness measured after the corresponding cold storage period (PROC REG in SAS v. 9.2).

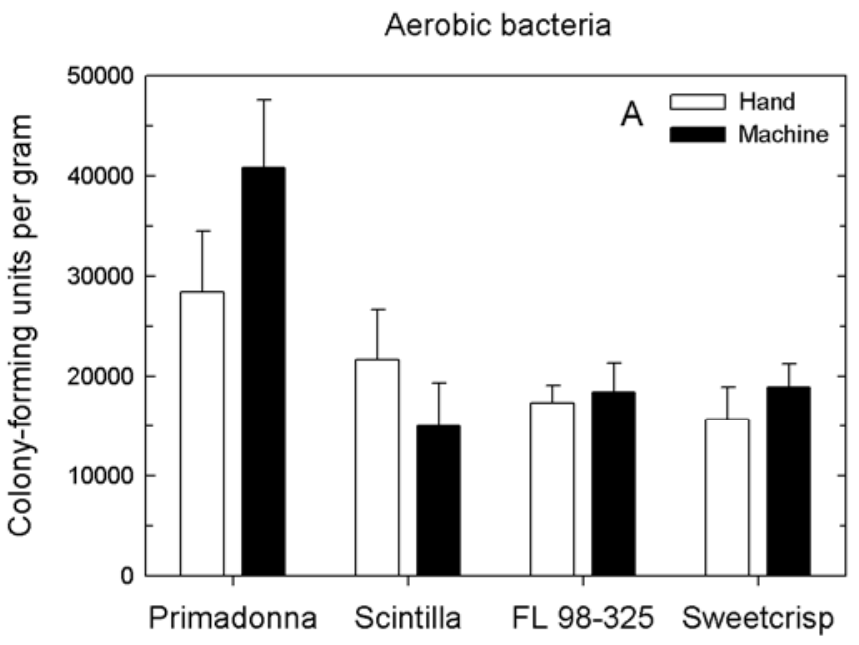

Total yeasts

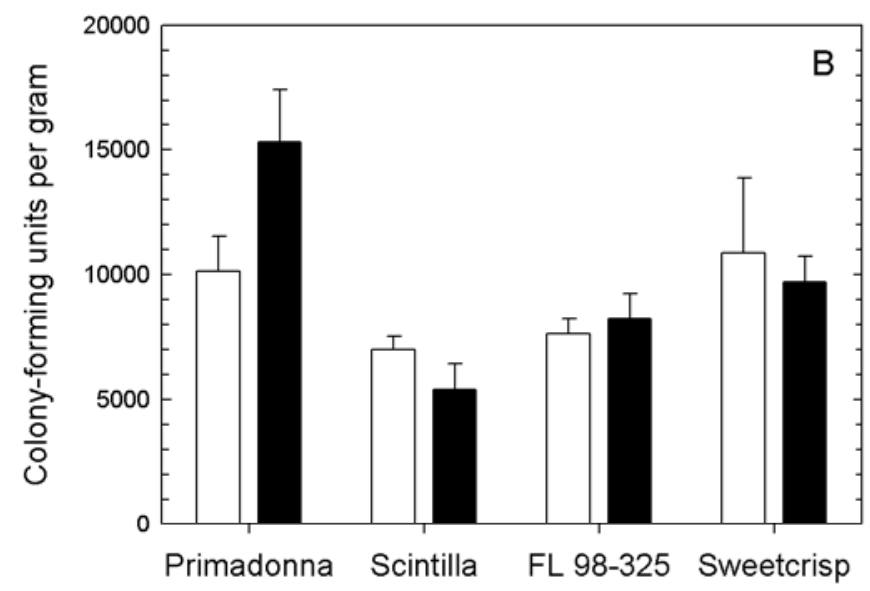

Total mold

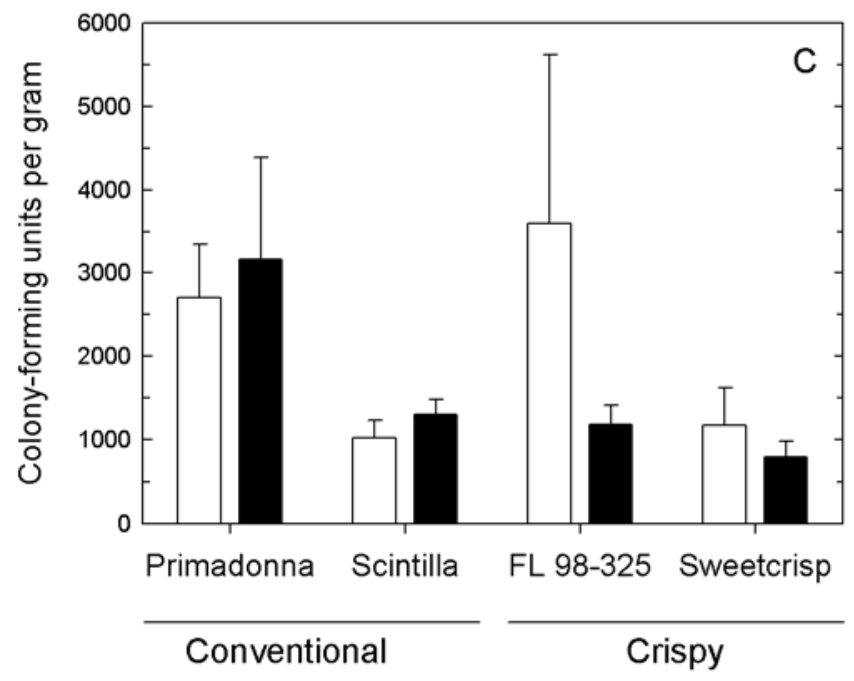

Fungal pathogens associated with diseased fruit were identified macroscopically and microscopically based on symptoms and signs (3,50). Microscopic identification was accomplished by removing fungal material (mycelium or condia) from affected fruit with a sterile transfer needle and observing under a compound microscope at $\times 400$ magnification. Frequencies were computed as the proportion of each species out of the total number of affected
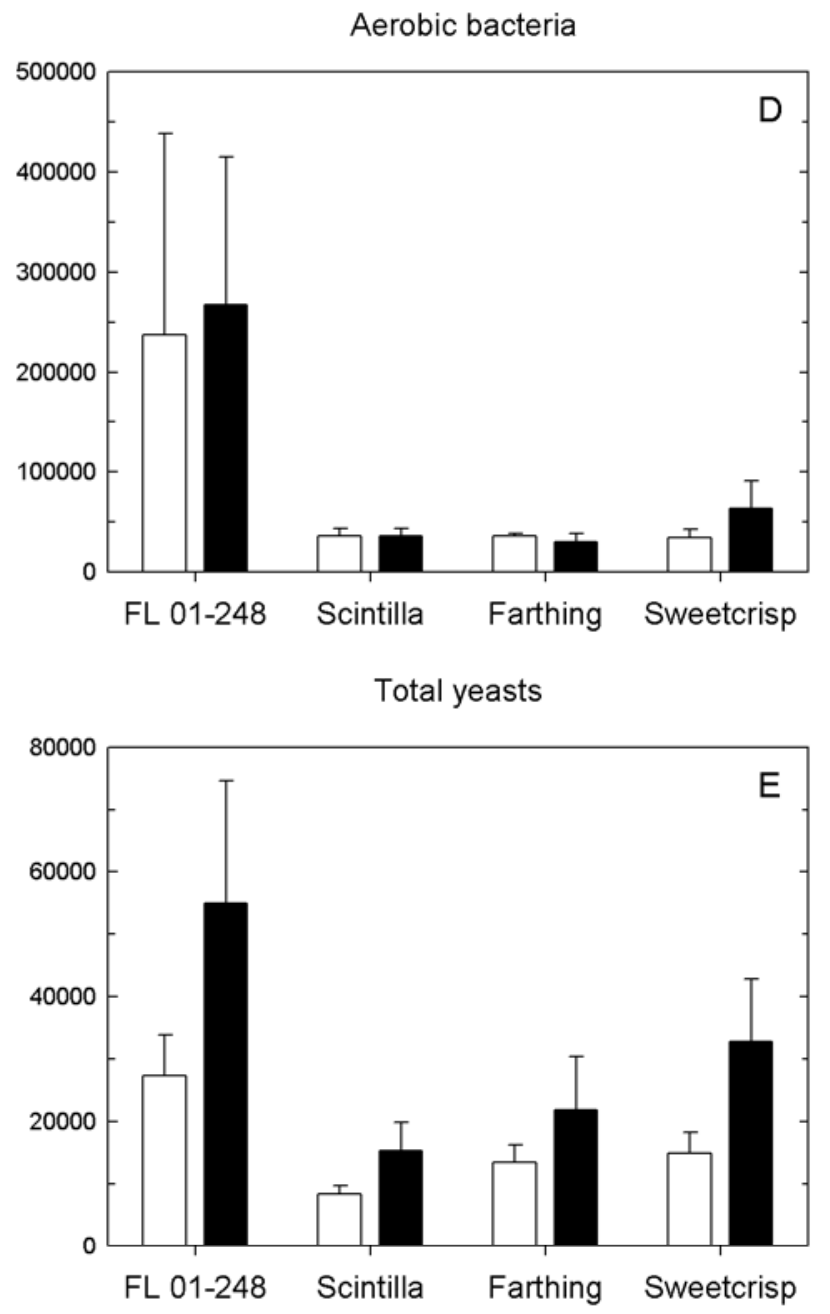

Total mold

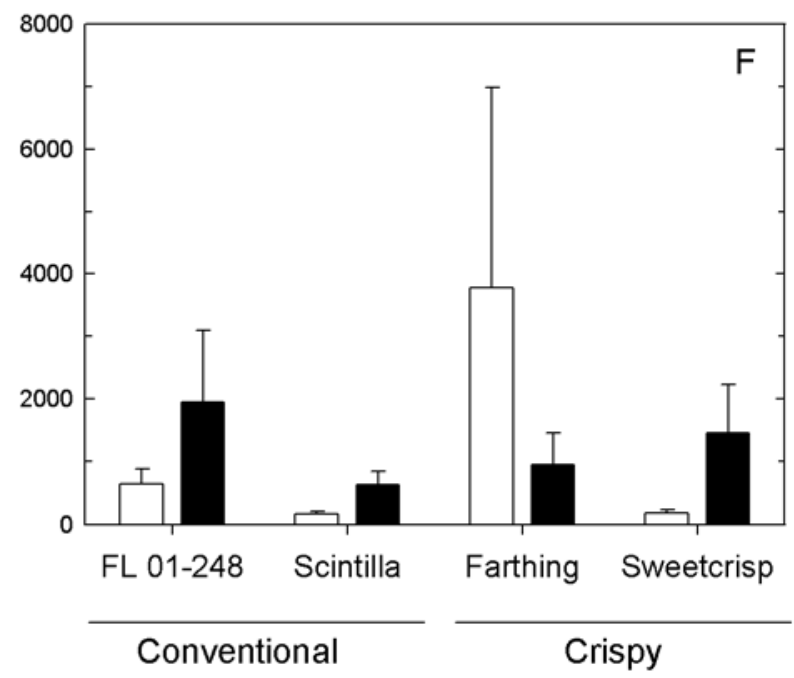

Fig. 1. Plate counts of aerobic bacteria, total yeasts, and total molds from the fruit surface of four southern highbush blueberry genotypes grouped into conventional and crisptextured fruit flesh types and subjected to hand- or machine-harvest in 2009 (A, B, and C) and 2010 (D, E, and F). Values are means and standard errors of four replicates. 
fruit. In addition, different fungal morphotypes were isolated for examination of pure cultures by transferring fungal material onto agar medium using a sterile transfer needle; total DNA was extracted (DNeasy Plant Kit, Qiagen, Valencia, CA) from purified cultures for amplification of the internal transcribed spacer (ITS) region using primers ITS-F and ITS-4 (17,51), followed by sequencing and a BLAST search against the NCBI database to confirm identifications.

Postharvest disease incidence after artificial inoculation. Artificial inoculations were carried out with $A$. alternata BAALM09I (isolated originally from symptomatic blueberry fruit), $B$. cinerea GBCLM09I (obtained from infected flowers of a Geranium sp.), and $C$. acutatum BCGLM09I (isolated from symptomatic blueberry fruit). The isolate of Alternaria was identified as belonging to the alternata species group based on the morphological key in Pryor and Michailides (42), and confirmed by amplification of the ITS region with primers ITS1-F and ITS4, which upon sequencing and BLAST search in the NCBI database yielded a perfect match with several A. alternata strains. The Colletotrichum isolate was identified as $C$. acutatum based on PCR amplification of total fungal DNA with primer ITS-4 coupled with species-specific primers CaInt2 (for a C. acutatum) or CgInt (for C. gloeosporioides) $(14,49)$. All isolates were maintained on agar slants at $7^{\circ} \mathrm{C}$ for long-term storage and grown on potato dextrose agar $(B$. cinerea and C. acutatum) or V8 juice agar (A. alternata) prior to use.

Fruit from the 0-day cold storage period were employed in the artificial inoculation experiments, using the same genotype and harvest method combinations mentioned for the natural postharvest disease development experiments above. Experimental units consisted of 50 fruit per replicate, placed stem end up in two or three petri dishes (100 $\mathrm{mm}$ diameter, $25 \mathrm{~mm}$ depth) on Whatman No. 1 filter paper moistened with $1 \mathrm{ml}$ of sterile deionized water. Each fruit was inoculated on the stem end with a $20-\mu l$ drop of a spore suspension $\left(1 \times 10^{5}\right.$ conidia per $\left.\mathrm{ml}\right)$ of one of the three fungal species. An untreated control group consisted of fruit inoculated with 20 $\mu \mathrm{l}$ of sterile distilled water on the stem scar. Inoculated fruit were incubated at 23 to $25^{\circ} \mathrm{C}$ for $24 \mathrm{~h}$ followed by $7^{\circ} \mathrm{C}$ for 7 days. After another $72 \mathrm{~h} \mathrm{(2009)}$ or $60 \mathrm{~h}(2010)$ at 23 to $25^{\circ} \mathrm{C}$, each berry was observed at $\times 10$ to $\times 63$ magnification for presence of symptoms or fungal signs. Separately for each pathogen, percent disease incidence was arcsine square-root transformed and subjected to split-plot analysis of variance with genotype (or flesh type group) as the mainplot and harvest method as the subplot using PROC GLIMMIX.

\section{Results}

Fruit surface contaminants. In both years, average counts of aerobic bacteria, total yeasts, and total molds were below commer-

Table 1. Results of a split-plot analysis of variance for the effects of fruit flesh type (conventional versus crisp-textured) ${ }^{\mathrm{z}}$ and harvest method (hand- versus machine-harvest) on plate counts of aerobic bacteria, total yeasts, and total molds on southern highbush blueberry fruit in 2009 and 2010

\begin{tabular}{|c|c|c|c|c|c|c|c|c|}
\hline \multirow[b]{2}{*}{ Source } & \multicolumn{4}{|c|}{2009} & \multicolumn{4}{|c|}{2010} \\
\hline & ndf & ddf & $\boldsymbol{F}$ & $P$ & ndf & ddf & $F$ & $P$ \\
\hline \multicolumn{9}{|l|}{ Aerobic bacteria } \\
\hline Flesh type (F) & 1 & 6 & 4.59 & 0.076 & 1 & 6.16 & 2.51 & 0.163 \\
\hline Harvest (H) & 1 & 22 & 0.090 & 0.768 & 1 & 21.5 & 0.450 & 0.510 \\
\hline $\mathrm{F} \times \mathrm{H}$ & 1 & 22 & 0.160 & 0.688 & 1 & 21.5 & 0.290 & 0.597 \\
\hline \multicolumn{9}{|l|}{ Total yeast } \\
\hline Flesh type (F) & 1 & 6 & 0.030 & 0.859 & 1 & 6 & 0.130 & 0.728 \\
\hline Harvest (H) & 1 & 22 & 0.050 & 0.822 & 1 & 22 & 4.27 & 0.051 \\
\hline $\mathrm{F} \times \mathrm{H}$ & 1 & 22 & 0.010 & 0.936 & 1 & 22 & 0.000 & 0.971 \\
\hline \multicolumn{9}{|l|}{ Total mold } \\
\hline Flesh type $(\mathrm{F})$ & 1 & 6 & 1.21 & 0.313 & 1 & 6 & 0.040 & 0.846 \\
\hline Harvest $(\mathrm{H})$ & 1 & 22 & 0.640 & 0.431 & 1 & 22 & 2.26 & 0.147 \\
\hline $\mathrm{F} \times \mathrm{H}$ & 1 & 22 & 2.46 & 0.131 & 1 & 22 & 0.570 & 0.456 \\
\hline
\end{tabular}

${ }^{\mathrm{z}}$ Conventional flesh genotypes included Primadonna and Scintilla in 2009, and FL 01-248 and Scintilla in 2010. Crisp-textured flesh genotypes were FL 98 325 and Sweetcrisp in 2009, and Farthing and Sweetcrisp in 2010.



Days in cold storage ( +4 days at room temperature)

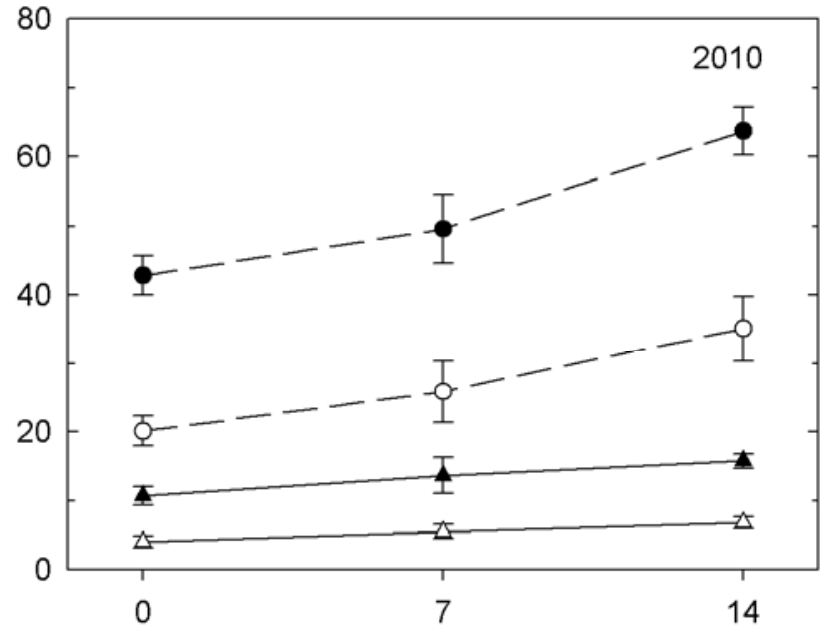

Days in cold storage (+4 days at room temperature)

Fig. 2. Natural postharvest disease incidence on fruit of conventional versus crisp-textured southern highbush blueberry genotypes harvested either by hand or machine and left in cold storage $\left(2^{\circ} \mathrm{C}\right)$ for different periods of time. Fruit were kept at room temperature $\left(23\right.$ to $\left.25^{\circ} \mathrm{C}\right)$ for an additional 4 days after removal from cold storage to increase disease pressure. Values are means and standard errors of four replicates of two cultivars each (Scintilla and Star with conventional flesh and Farthing and Sweetcrisp with crispy flesh). 
cial thresholds used typically for processed blueberries, i.e., $100,000 \mathrm{CFU} / \mathrm{g}$ for aerobic bacteria and 75,000 CFU/g for yeasts and molds (U.S. Highbush Blueberry Council, Folsom, CA, unpublished $)$, with the exception of FL 01-248 in $2010\left(2.5 \times 10^{5}\right.$ $\mathrm{CFU} / \mathrm{g}$ of aerobic bacteria). In general, microbial counts were higher in 2010 than in 2009 (Fig. 1), especially for aerobic bacteria on FL 01-248 and for yeasts on all genotypes. There were no statistically significant effects of flesh type (conventional versus crispy genotype group) and harvest method on microbial counts (Table 1). However, when data were analyzed for individual genotypes, counts of aerobic bacteria and yeasts were significantly higher on FL 01-248 in 2010 than on all other genotypes $(P=$ 0.0236 and 0.0207 , respectively).

No colonies of $E$. coli were detected in either year; however, some coliform colonies were present in one replicate of hand-harvested Primadonna in 2009 (average 7.0 CFU/g) and in machineharvested replicates of Farthing and Sweetcrisp in 2010 (averages 1.0 and $20.0 \mathrm{CFU} / \mathrm{g}$, respectively).

Natural postharvest disease incidence. In both years, disease incidence increased as the duration of the cold storage period increased (Fig. 2), although disease levels were considerably higher in 2010 than in 2009. Fruit of machine-harvested conventional genotypes developed the highest disease, and those of hand-harvested crispy genotypes had the lowest disease in both years. Interestingly, machine-harvested crispy fruit performed at least as well as or better than hand-harvested conventional fruit in both years (Fig. 2, Table 2). When data were analyzed for individual genotypes (Table 3), Farthing (a crisp-textured cultivar) performed best and Scintilla (a conventional cultivar) performed worst in 2009. In 2010, Farthing and Sweetcrisp (both crispy flesh cultivars) were better (had lower disease incidence) than Scintilla and Star (both conventional cultivars).

Negative relationships were observed between postharvest disease incidence and fruit firmness (4 days before disease assessment, when fruit were removed from cold storage) in both years (Fig. 3). In 2009, fruit firmness values $>220 \mathrm{~g} / \mathrm{mm}$ were associated with consistently low disease incidence. However, few fruit samples reached or exceeded this firmness value in 2010.

Alternaria spp., Cladosporium spp., and Aureobasidium pullulans were the most common fungi naturally associated with postharvest decay in this study (Fig. 4); however, there was a higher proportion of Colletotrichum spp. in 2010 than in 2009. Other fungi found on diseased fruit were Pestalotiopsis spp., B. cinerea, and Penicillium spp. Overall, the complex of postharvest decay fungi was similar for the conventional and crispy genotype groups and for hand- and machine-harvested fruit (Fig. 4).

Postharvest disease incidence after artificial inoculation. In both years, fruit of crispy flesh genotypes developed significantly lower disease than those of conventional flesh genotypes following artificial inoculation with A. alternata, B. cinerea, or C. acutatum (Fig. 5, Table 4). In 2009, Scintilla (conventional flesh) developed the highest disease ( $~ 80$ to $90 \%$ incidence) as a result of $A$. alternata and $B$. cinerea inoculation. On the other hand, Farthing and Sweetcrisp (both crispy flesh) developed the lowest disease ( $\sim 40$ to $50 \%$ incidence) in response to B. cinerea and C. acutatum inoculation, respectively (Fig. 5). In 2010, Sweetcrisp (crispy flesh) developed relatively low levels of disease, whereas Star (conventional) developed the highest disease after artificial inoculation. There was no significant effect of harvest method except for inoculation with A. alternata in

Table 2. Results of a split-split-plot analysis of variance for the effects of fruit flesh type (conventional versus crisp-textured) ${ }^{\mathrm{y}}$, harvest method (hand- versus machine-harvest), and time on natural postharvest disease incidence on southern highbush blueberry fruit in 2009 and 2010

\begin{tabular}{|c|c|c|c|c|c|c|c|c|}
\hline \multirow[b]{2}{*}{ Source } & \multicolumn{4}{|c|}{2009} & \multicolumn{4}{|c|}{2010} \\
\hline & ndf & ddf & $F$ & $P$ & ndf & ddf & $F$ & $P$ \\
\hline Flesh type $(F)$ & 1 & 6 & 58.8 & 0.0003 & 1 & 6 & 420.7 & $<0.0001$ \\
\hline Harvest $(\mathrm{H})$ & 1 & 6 & 65.6 & 0.0002 & 1 & 6 & 137.9 & $<0.0001$ \\
\hline $\mathrm{F} \times \mathrm{H}$ & 1 & 6 & 0.860 & 0.389 & 1 & 6 & 13.2 & 0.011 \\
\hline Time $(\mathrm{T})^{\mathrm{z}}$ & 3 & 100 & 37.0 & $<0.0001$ & 2 & 72 & 12.8 & $<0.0001$ \\
\hline $\mathrm{T} \times \mathrm{F}$ & 3 & 100 & 1.18 & 0.320 & 2 & 72 & 2.61 & 0.080 \\
\hline $\mathrm{T} \times \mathrm{H}$ & 3 & 100 & 3.72 & 0.013 & 2 & 72 & 0.190 & 0.825 \\
\hline $\mathrm{T} \times \mathrm{F} \times \mathrm{H}$ & 3 & 100 & 0.600 & 0.618 & 2 & 72 & 0.110 & 0.899 \\
\hline
\end{tabular}

y Genotypes included Scintilla and Star with conventional flesh and Farthing and Sweetcrisp with crisp-textured flesh.

${ }^{\mathrm{z}}$ Disease assessments made after $0,7,14$, and 21 ( 2009 only) days in cold storage $\left(2^{\circ} \mathrm{C}\right)$ followed by an additional 4 days at room temperature $\left(23\right.$ to $\left.25^{\circ} \mathrm{C}\right)$ to increase disease pressure.

Table 3. Natural postharvest disease incidence (\%) on fruit of southern highbush blueberry genotypes having conventional or crisp-textured fruit flesh type subjected to hand- or machine-harvest and maintained in cold storage $\left(2^{\circ} \mathrm{C}\right)$ for different periods of time ${ }^{\mathrm{y}}$

\begin{tabular}{|c|c|c|c|c|c|c|c|c|}
\hline \multirow[b]{3}{*}{ Year/genotype } & \multicolumn{8}{|c|}{ Cold storage period ${ }^{\mathrm{z}}$ (days after harvest) } \\
\hline & \multicolumn{2}{|c|}{$\mathbf{0}$} & \multicolumn{2}{|c|}{7} & \multicolumn{2}{|c|}{14} & \multicolumn{2}{|c|}{21} \\
\hline & Hand & Machine & Hand & Machine & Hand & Machine & Hand & Machine \\
\hline \multicolumn{9}{|l|}{2009} \\
\hline \multicolumn{9}{|l|}{ Conventional } \\
\hline Star & $2.04 \mathrm{~b}$ & $5.40 \mathrm{a}$ & $5.24 \mathrm{~b}$ & $17.2 \mathrm{~b}$ & $6.06 \mathrm{~b}$ & $23.0 \mathrm{~b}$ & $7.28 \mathrm{~b}$ & $21.1 \mathrm{~b}$ \\
\hline Scintilla & $7.21 \mathrm{a}$ & $3.35 \mathrm{a}$ & $14.6 \mathrm{a}$ & $27.5 \mathrm{a}$ & $17.5 \mathrm{a}$ & $29.1 \mathrm{a}$ & $28.6 \mathrm{a}$ & $48.5 \mathrm{a}$ \\
\hline \multicolumn{9}{|l|}{ Crisp-textured } \\
\hline Farthing & $0.533 \mathrm{~b}$ & $0.473 \mathrm{a}$ & $1.80 \mathrm{~b}$ & $1.76 \mathrm{c}$ & $3.05 \mathrm{~b}$ & $6.73 c$ & $5.72 \mathrm{~b}$ & $8.31 \mathrm{c}$ \\
\hline Sweetcrisp & $0.358 \mathrm{~b}$ & $2.87 \mathrm{a}$ & $1.14 \mathrm{~b}$ & $12.9 \mathrm{~b}$ & $5.34 \mathrm{~b}$ & $11.3 \mathrm{c}$ & $4.49 \mathrm{~b}$ & $21.4 \mathrm{~b}$ \\
\hline \multicolumn{9}{|l|}{2010} \\
\hline \multicolumn{9}{|l|}{ Conventional } \\
\hline Star & $24.3 \mathrm{a}$ & $47.6 \mathrm{a}$ & $19.9 \mathrm{a}$ & $40.2 \mathrm{~b}$ & $37.8 \mathrm{a}$ & $64.6 \mathrm{a}$ & $\ldots$ & $\ldots$ \\
\hline Scintilla & $15.8 \mathrm{~b}$ & $38.1 \mathrm{~b}$ & $31.7 \mathrm{a}$ & $58.9 \mathrm{a}$ & $32.3 \mathrm{a}$ & $62.8 \mathrm{a}$ & $\ldots$ & $\ldots$ \\
\hline \multicolumn{9}{|l|}{ Crisp-textured } \\
\hline Farthing & $3.74 \mathrm{c}$ & $8.61 \mathrm{c}$ & $5.31 \mathrm{~b}$ & $10.3 \mathrm{c}$ & $6.62 \mathrm{~b}$ & $13.6 \mathrm{~b}$ & $\ldots$ & $\ldots$ \\
\hline Sweetcrisp & $4.26 \mathrm{c}$ & $12.7 \mathrm{c}$ & $5.61 \mathrm{~b}$ & $17.0 \mathrm{c}$ & $6.90 \mathrm{~b}$ & $17.7 \mathrm{~b}$ & $\ldots$ & $\ldots$ \\
\hline
\end{tabular}

${ }^{y}$ Values are means of four replicates. Within each column and year, means followed by the same letter are not significantly different according to Fisher's Protected LSD test $(\alpha=0.05)$.

${ }^{\mathrm{z}}$ Fruit were maintained at room temperature $\left(23\right.$ to $\left.25^{\circ} \mathrm{C}\right)$ for an additional 4 days following the cold storage period to increase disease pressure. 

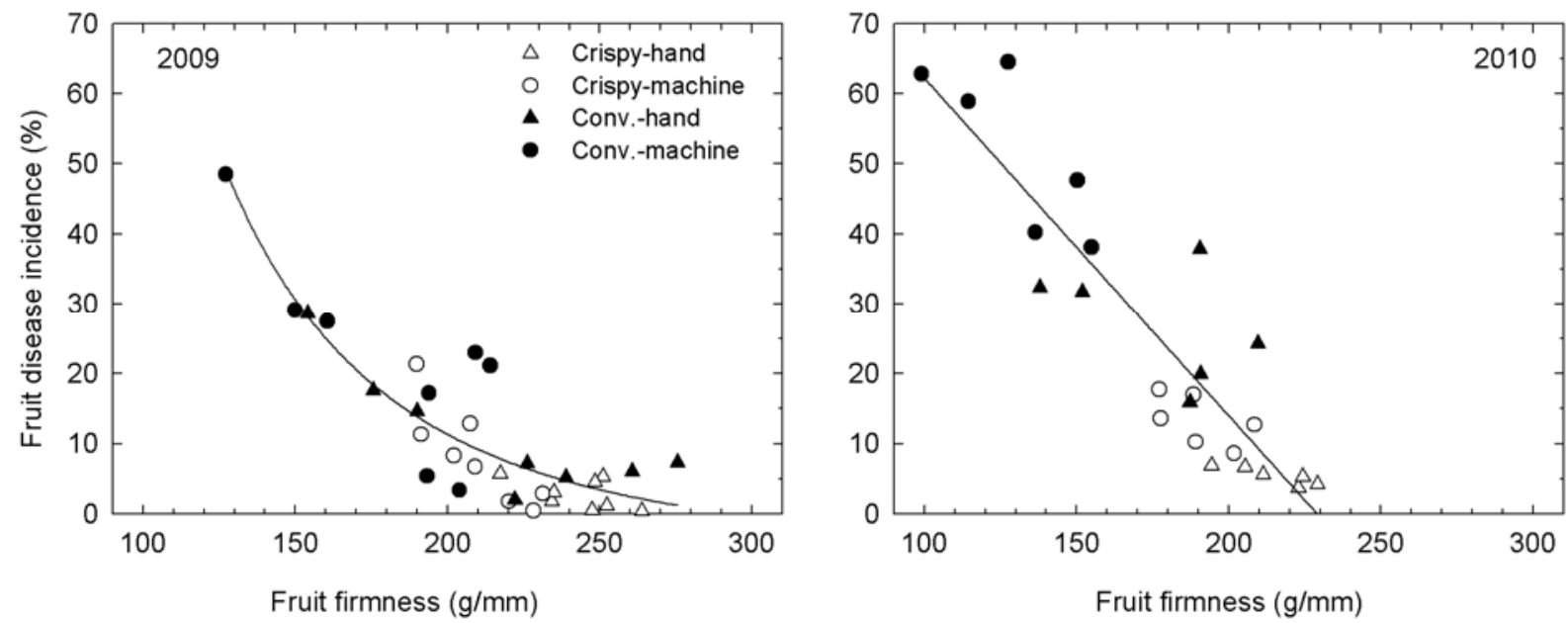

Fig. 3. Relationship between natural postharvest disease incidence and firmness for fruit of southern highbush blueberry genotypes with conventional or crisp-textured fruit flesh type subjected to hand- or machine-harvest and maintained in cold storage $\left(2^{\circ} \mathrm{C}\right)$ for different periods of time. Same genotype, harvest method, and storage period combinations as in Table 3. Curves represent the lines of best fit by least-squares regression analysis $(r=0.897$ and 0.902 in 2009 and 2010, respectively; $P<0.0001)$.


Fig. 4. Relative proportion of different fungal genera associated with natural postharvest disease on fruit of southern highbush blueberry genotypes with conventional or crisptextured fruit flesh type subjected to hand- or machine-harvest and maintained in cold storage $\left(2^{\circ} \mathrm{C}\right)$ for different periods of time. Same genotype, harvest method, and storage period combinations as in Table 3. 
2009 (Table 4), where hand-harvested fruit had lower levels of disease than machine-harvested fruit.

\section{Discussion}

Taken together, results from this study show that mechanical harvesting of crisp-textured SHB genotypes is feasible from a postharvest pathology perspective. When exposed to natural inoculum, machine-harvested fruit of crispy flesh genotypes developed levels of natural postharvest decay lower or similar to those of hand-harvested fruit of conventional flesh genotypes. Results of artificial inoculation with $A$. alternata, B. cinerea, and $C$. acutatum supported the fact that crispy berries develop less postharvest dis-
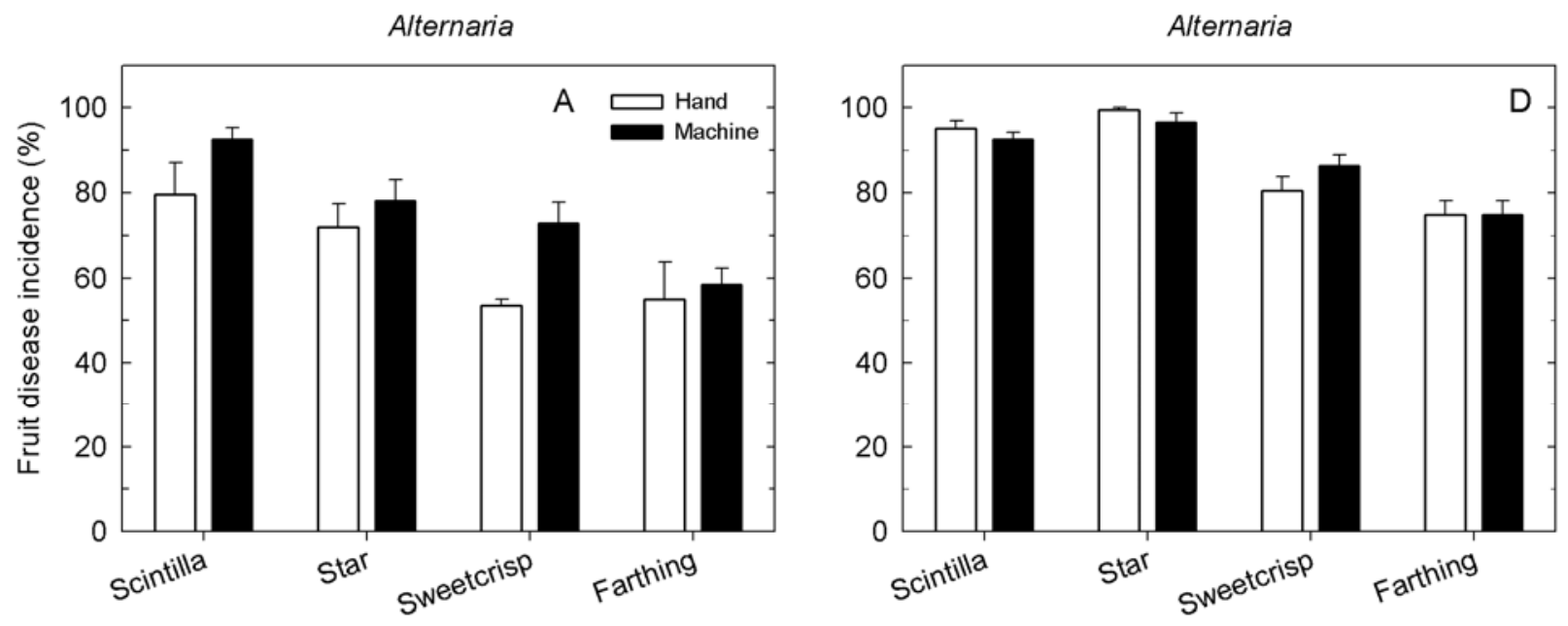

Botrytis

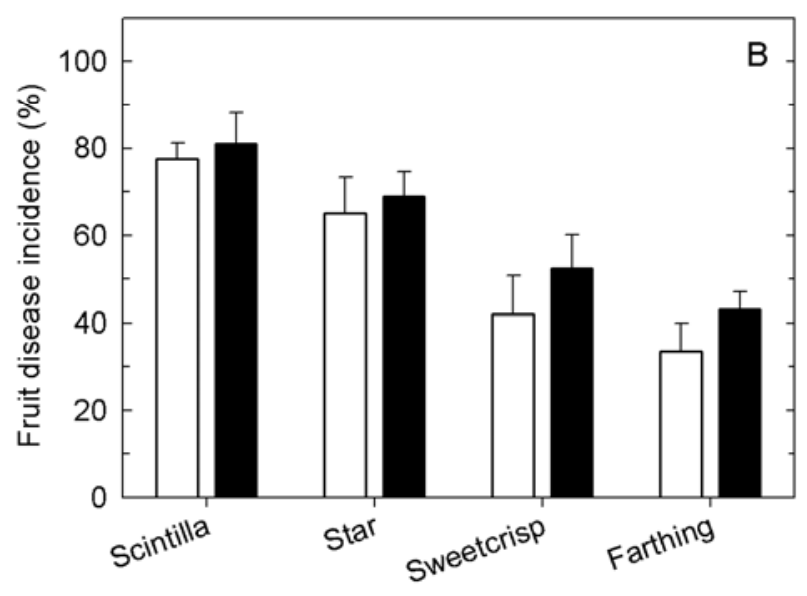

Botrytis



Colletotrichum

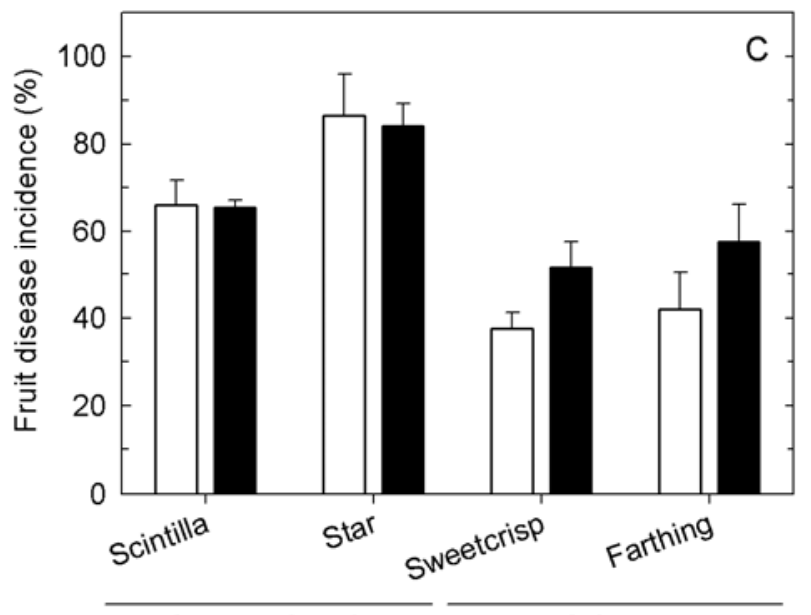

Conventional

Crispy

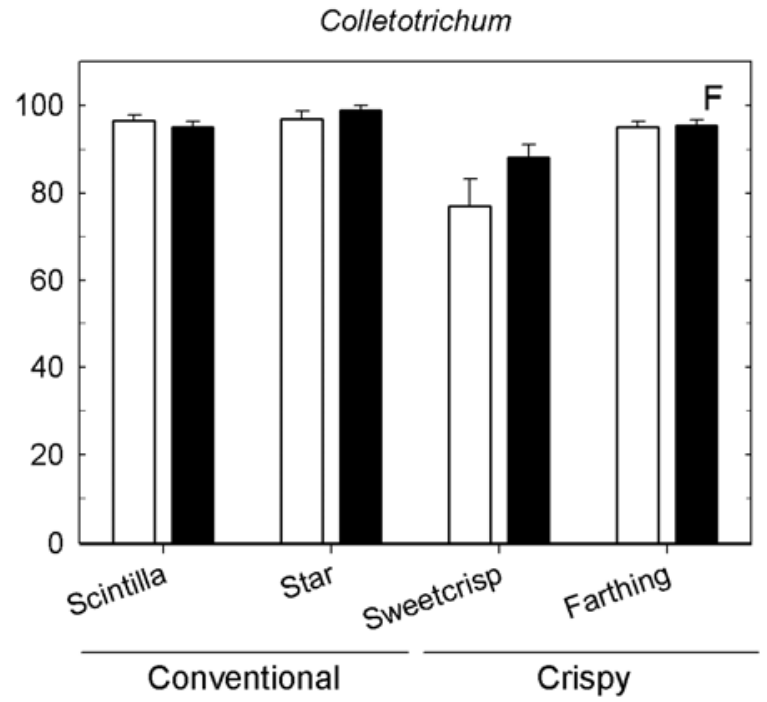

Fig. 5. Percent fruit disease incidence following artificial inoculation with Alternaria alternata, Botrytis cinerea, or Colletotrichum acutatum on four southern highbush blueberry genotypes grouped into conventional and crisp-textured fruit flesh types and subjected to hand- or machine-harvest in 2009 (A, B, and C) and 2010 (D, E, and F). Values are means and standard errors of four replicates. Natural disease incidence in the water control in 2009 and 2010 , respectively, averaged 7.9 and $17.9 \%$ for Alternaria, 0.25 and $1.9 \%$ for Botrytis, and 0.63 and $5.2 \%$ for Colletotrichum (data not shown). 
Table 4. Results of a split-plot analysis of variance for the effects of fruit flesh type (conventional versus crisp-textured) $\mathrm{z}$ and harvest method (hand- versus machine-harvest) on postharvest disease incidence following artificial inoculation with Alternaria alternata, Botrytis cinerea, or Colletotrichum acutatum on southern highbush blueberry fruit in 2009 and 2010

\begin{tabular}{|c|c|c|c|c|c|c|c|c|}
\hline \multirow[b]{2}{*}{ Source } & \multicolumn{4}{|c|}{2009} & \multicolumn{4}{|c|}{2010} \\
\hline & ndf & ddf & $\boldsymbol{F}$ & $P$ & ndf & ddf & $F$ & $P$ \\
\hline \multicolumn{9}{|l|}{ A. alternata } \\
\hline Flesh type (F) & 1 & 6 & 24.4 & 0.003 & 1 & 6 & 155.9 & $<0.0001$ \\
\hline Harvest $(\mathrm{H})$ & 1 & 22 & 6.26 & 0.020 & 1 & 22 & 0.320 & 0.577 \\
\hline $\mathrm{F} \times \mathrm{H}$ & 1 & 22 & 0.040 & 0.844 & 1 & 22 & 2.42 & 0.134 \\
\hline \multicolumn{9}{|l|}{ B. cinerea } \\
\hline Flesh type (F) & 1 & 6 & 65.5 & 0.0002 & 1 & 6 & 180.0 & $<0.0001$ \\
\hline Harvest $(\mathrm{H})$ & 1 & 22 & 1.80 & 0.194 & 1 & 22 & 0.740 & 0.399 \\
\hline $\mathrm{F} \times \mathrm{H}$ & 1 & 22 & 0.190 & 0.666 & 1 & 22 & 3.39 & 0.079 \\
\hline \multicolumn{9}{|l|}{ C. acutatum } \\
\hline Flesh type (F) & 1 & 6 & 29.8 & 0.0016 & 1 & 6 & 13.2 & 0.011 \\
\hline Harvest $(\mathrm{H})$ & 1 & 22 & 0.580 & 0.454 & 1 & 22 & 0.830 & 0.372 \\
\hline $\mathrm{F} \times \mathrm{H}$ & 1 & 22 & 2.37 & 0.138 & 1 & 22 & 0.540 & 0.468 \\
\hline
\end{tabular}

${ }^{\mathrm{z}}$ Genotypes included Scintilla and Star with conventional flesh and Farthing and Sweetcrisp with crisp-textured flesh.

ease than their conventional flesh counterparts, regardless of harvest method. In the only published study characterizing the crisptextured berry type (37), it has been shown that fruit of the crispy genotypes are firmer and more "springy" than those of their conventional counterparts; this could explain the lower postharvest disease levels via two different, but related, mechanisms: (i) because of their firmer texture, crispy berries are inherently more resistant to direct penetration by fungal pathogens; and (ii) the greater firmness of crispy berries allows lower levels of bruising to occur during harvest, thereby reducing the level of wound-associated infection.

Our study documented a negative association between postharvest disease incidence and fruit firmness across genotypes and harvest methods, indicating that fruit firmness is a good predictor for postharvest decay. This relationship also suggests that the lower level of postharvest disease in crispy flesh genotypes is mostly due to their greater firmness, and not some other form of genetic resistance. Similarly, the higher disease incidence in 2010 compared with 2009 was likely due to lower values of fruit firmness, possibly due to hotter temperatures, reaching up to $35^{\circ} \mathrm{C}$ during harvest, and/or higher rainfall before harvest in 2010. It is well established that fruit firmness is inversely related to temperature and can vary from year to year for the same cultivar $(2,36)$. Also, early ripening is generally associated with higher fruit firmness (52), which may be the cause of better firmness levels in 2009 compared with 2010, when harvest was delayed by about 2 weeks due to weather.

Mechanical harvesters for blueberries were first developed in the early 1960s and have been improved since then to produce higher quality fruit $(30,39,40,47)$. A major concern with mechanical harvest has been fruit bruising, which occurs as a result of direct contact between the berries and the harvester's beater rods, when detached berries drop from the bush into the harvester's catch pans, during passage of the berries from the catch pans to the conveyor belt, and when the berries drop from the conveyor belt into the fruit lugs (7). Bruising increases with longer falling distance on harder surfaces of the harvester (2) and reduces both external and internal fruit quality $(11,31,36)$. Internal damage to the fruit results in cellular water leakage and development of water-soaked areas in the flesh (21). Recent work with a miniaturized instrumented sphere has shown that dropping on the catch pan accounted for $>30 \%$ of all impacts in a mechanical blueberry harvester similar to that used in the current study, and that these drop impacts can be reduced by applying cellular silicone as a padding material (54). Such improvements in mechanical harvesting technology, together with the favorable results obtained in the current study for fruit firmness and postharvest disease development on crisp-textured genotypes, bode well for the potential of machine-harvesting crispy flesh SHB in commercial conditions.

In addition to bruising and postharvest decay, however, there are other drawbacks to machine-harvesting that can increase losses and reduce quality and revenue. These include ground losses, excessive green fruit detachment, delayed harvest, ripe fruit remaining on the bush, and cane damage $(2,31,36,47)$. Overall, therefore, a systems approach integrating cultural and engineering practices is needed to reduce these potential sources of losses associated with machine-harvest.

Although the fruit firmness groups and harvest methods differed in postharvest disease incidence in our study, the pathogen complex responsible was similar across treatments. Aureobasidium pullulans, Cladosporium spp. (both usually considered opportunistic pathogens), and Alternaria spp. were observed most commonly. Pathogens such as B. cinerea and Colletotrichum spp. that are common in other blueberry growing areas of the United States $(8,33,45,46,48)$ were also observed, albeit in smaller proportions (except for a higher incidence of Colletotrichum spp. in 2010). Higher temperature and rainfall before harvest could have increased the incidence of Colletotrichum spp. in 2010. Since the focus of these experiments was on disease development during the entire postharvest chain, the disease incidence values reported here include both infections that occurred preharvest and remained symptomless until after harvest, and those that occurred opportunistically on bruised fruit during postharvest handling and storage.

Although this study demonstrated that mechanical harvest of the novel crisp-textured SHB cultivars is feasible from a postharvest pathology perspective, further research is needed to address potential problems related to in-field losses, postharvest quality, and consumer acceptance of machine-harvested crispy berries. We are collaborating with plant breeders, horticulturists, postharvest physiologists, and food scientists to investigate these aspects comprehensively and develop an integrated system for production, harvest, and marketing of mechanically harvested SHB.

\section{Acknowledgments}

We thank Gerard Krewer and Fumi Takeda for coordinating the mechanical harvest experiments. Access to field sites and logistical support by Alto Straughn, Paul Lyrene, and Jim Olmstead is greatly appreciated. We also acknowledge Oxbo International for providing a Korvan 8000 harvester on loan. Funded by USDA-NIFA grant no. 2008-51180-19579 (Specialty Crop Research Initiative).

\section{Literature Cited}

1. Anonymous. 2010. U.S. Noncitrus fruits and nuts, 2009 summary. Fr Nt 12(10), U.S. Dep. Agric.-NASS, Washington, DC.

2. Ballinger, W. E., Kushman, L. J., and Hamann, D. D. 1973. Factors affecting the firmness of highbush blueberries. J. Am. Soc. Hortic. Sci. 98:583587.

3. Barnett, H. L., and Hunter, B. B. 1987. Illustrated Genera of Imperfect Fungi. Macmillan, New York.

4. Barrau, C., de los Santos, B., and Romero, F. 2006. Susceptibility of southern highbush and rabbiteye blueberry cultivars to postharvest diseases in Huelva, Spain. Acta Hortic. 715:525-530.

5. Boatright, S. R., and McKissick, J. C. 2010. 2009 Georgia farm gate fruits 
and nuts report. AR-10-04, College of Agricultural and Environmental Sciences, University of Georgia, Athens.

6. Boatright, S. R., and McKissick, J. C. 2010. 2009 Georgia farm gate value report. AR-10-01, College of Agricultural and Environmental Sciences, University of Georgia, Athens.

7. Brown, G. K., Schulte, N. L., Timm, E. J., Beaudry, R. M., Peterson, D. L., Hancock, J. F., and Takeda, F. 1996. Estimates of mechanization effects on fresh blueberry quality. Appl. Eng. Agric. 12:21-26.

8. Cappellini, R. A., Ceponis, M. J., and Koslow, G. 1982. Nature and extent of losses in consumer-grade samples of blueberries in greater New York. HortScience 17:55-56.

9. Ceponis, M. J., and Cappellini, R. A. 1979. Control of post-harvest decays of blueberry fruits by precooling, fungicide, and modified atmospheres. Plant Dis. Rep. 63:1049-1053.

10. Cline, W. O. 1996. Postharvest infection of highbush blueberries following contact with infested surfaces. HortScience 31:981-983.

11. Dale, A., Hanson, E. J., Yarborough, D. E., McNicol, R. J., Stang, E. J., Brennan, R., Morris, J. R., and Hergert, G. B. 1994. Mechanical harvesting of berry crops. Hortic. Rev. 6:255-383.

12. Daykin, M. E., and Milholland, R. D. 1984. Infection of blueberry fruit by Colletotrichum gloeosporioides. Plant Dis. 68:948-950.

13. Fonsah, E. G., Krewer, G., Harrison, K., and Bruorton, M. 2006. Economic analysis of producing southern highbush blueberries in Georgia. Bull. 1303, College of Agricultural and Environmental Sciences, University of Georgia, Athens.

14. Freeman, S., Minz, D., Jurkevitch, E., Maymon, M., and Shabi, E. 2000. Molecular analyses of Colletotrichum species from almond and other fruits. Phytopathology 90:608-614.

15. Funt, R. C., Wall, T. E., and Scheerens, J. C. 1998. Yield, berry quality, and economics of mechanical berry harvest in Ohio. Res. Circ. 299-99, Ohio State University, Columbus.

16. Gillett, J. M., and Schilder, A. C. 2009. Environmental requirements for infection of blueberry fruit by Colletotrichum acutatum. Acta Hortic. 810:355-360.

17. Glen, M., Tommerup, I. C., Bougher, N. L., and O'Brien, P. A. 2001. Specificity, sensitivity and discrimination of primers for PCR-RFLP of larger basidiomycetes and their applicability to identification of ectomycorrhizal fungi in Eucalyptus forests and plantations. Mycol. Res. 105:138-149.

18. Harmon, P. F. 2004. Botrytis blossom blight of southern highbush blueberry. PP198, IFAS Extension, University of Florida, Gainesville.

19. Krewer, G. 2010. 2010 Southeast regional blueberry integrated management guide. Dixie Blueberry News 10(1):9-55.

20. Krewer, G., and NeSmith, D. S. 2006. Blueberry cultivars for Georgia. Fruit Publ. 00-2, College of Agricultural and Environmental Sciences, University of Georgia, Athens.

21. Labavitch, J. M., Greve, L. C., and Mitcham, E. 1998. Fruit bruising: It's more than skin deep. Perishables Handling Quart. 95:7-9.

22. Lang, G. A. 1993. Southern highbush blueberries: Physiological and cultural factors important for optimal cropping of these complex hybrids. Acta Hortic. 346:72-80.

23. Lang, G. A., and Tao, J. 1992. Postharvest performance of southern highbush blueberry fruit. HortTechnology 2:366-370.

24. Lyrene, P. M. 1998. Low-chill highbush blueberry 'Star'. United States Patent PP10675, Patent Genius, USPT Office, Alexandria, VA.

25. Lyrene, P. M. 1999. Blueberry plant called 'Bluecrisp'. United States Patent PP19341, Patent Genius, USPT Office, Alexandria, VA.

26. Lyrene, P. M. 2008. Southern highbush blueberry plant named 'Farthing'. United States Patent PP11033, Patent Genius, USPT Office, Alexandria, VA.

27. Lyrene, P. M. 2008. Southern highbush blueberry plant named 'Scintilla'. United States Patent PP19233, Patent Genius, USPT Office, Alexandria, VA.

28. Lyrene, P. M. 2009. Southern highbush blueberry plant named 'Primadonna'. United States Patent PP20181, Patent Genius, USPT Office, Alexandria, VA.

29. Lyrene, P. M. 2009. 'Sweetcrisp' southern highbush blueberry plant. United States Patent PP20027, Patent Genius, USPT Office, Alexandria, VA.

30. Mainland, C. M. 1993. Blueberry production strategies. Acta Hortic. 346:111-116
31. Mainland, C. M., Kushman, L. J., and Ballinger, W. E. 1975. Effect of mechanical harvesting on yield, quality of fruit and bush damage of highbush blueberry. J. Am. Soc. Hortic. Sci. 100:129-134.

32. Makus, D. J., and Morris, J. R. 1993. A comparison of fruit of highbush and rabbiteye blueberry cultivars. J. Food Qual. 16:417-428.

33. Milholland, R. D., and Jones, R. K. 1972. Postharvest decay of highbush blueberry fruit in North Carolina. Plant Dis. Rep. 56:118-122.

34. Miller, W. R., McDonald, R. E., and Cracker, T. E. 1993. Quality of two Florida blueberry cultivars after packaging and storage. HortScience 28:144-147.

35. NeSmith, D. S. 2009. Blueberry cultivar development at the University of Georgia. Acta Hortic. 810:79-86.

36. NeSmith, D. S., Prussia, S., Tetteh, M., and Krewer, G. 2002. Firmness losses of rabbiteye blueberries (Vaccinium ashei Reade) during harvesting and handling. Acta Hortic. 574:287-293.

37. Padley, L. 2005. Firmness and Storage Characteristics of Crisp-Textured Blueberries. M.S. thesis. Department of Horticultural Sciences, University of Florida, Gainesville.

38. Perkins-Veazie, P., Collins, J. K., Clark, J. R., and Magee, J. 1994. Postharvest quality of southern highbush blueberries. Proc. Fla. State Hortic. Soc. 107:269-271

39. Peterson, D. L., and Brown, G. K. 1996. Mechanical harvester for fresh market quality blueberries. Trans. Am. Soc. Agric. Eng. 39:823-827.

40. Peterson, D. L., Wolford, S. D., Timm, E. J., and Takeda, F. 1997. Fresh market quality blueberry harvester. Trans. Am. Soc. Agric. Eng. 40:535 540.

41. Popa, I., Hanson, E. J., Todd, E. C. D., Schilder, A. C., and Ryser, E. T. 2007. Efficacy of chlorine dioxide gas sachets for enhancing the microbiological quality and safety of blueberries. J. Food Prot. 70:20842088.

42. Pryor, B. M., and Michailides, T. J. 2002. Morphological, pathogenic, and molecular characterization of Alternaria isolates associated with Alternaria late blight of pistachio. Phytopathology 92:406-416.

43. Safley, C. D., Cline, W. O., and Mainland, C. M. 2005. Estimated costs of producing, harvesting, and marketing blueberries in the southeastern United States. Pages 33-49 in: Proc. 12th Southeast. Blueberry Conf., Savannah, GA.

44. Scherm, H., and Krewer, G. 2003. Blueberry production in Georgia: Historical overview and recent trends. Small Fruits Rev. 2(4):83-91.

45. Schilder, A. M. C., Gillett, J. M., and Woodworth, J. A. 2002. The kaleidoscopic nature of blueberry fruit rots. Acta Hortic. 574:81-83.

46. Smith, B. J., Magee, J. B., and Gupton, C. L. 1996. Susceptibility of rabbiteye blueberry cultivars to postharvest diseases. Plant Dis. 80:215-218.

47. Takeda, F., Krewer, G., Andrews, E. L., Mullinix, B., and Peterson, D. L. 2008. Assessment of the v45 blueberry harvester on rabbiteye blueberry and southern highbush blueberry pruned to V-shaped canopy. HortTechnology $18: 130-138$

48. Tournas, V. H., and Katsoudas, E. 2005. Mould and yeast flora in fresh berries, grapes and citrus fruits. Int. J. Food Microbiol. 105:11-17.

49. Verma, N., MacDonald, L., and Punja, Z. K. 2006. Inoculum prevalence, host infection and biological control of Colletotrichum acutatum: Causal agent of blueberry anthracnose in British Columbia. Plant Pathol. 55:442 450.

50. Wharton, P., and Schilder, A. 2003. Blueberry fruit rot identification guide. Ext. Bull. E-2847, Michigan State University, East Lansing

51. White, T. J., Bruns, T., Lee, S., and Taylor, J. 1990. Amplification and direct sequencing of fungal ribosomal RNA genes for phylogenetics. Pages 315 322 in: PCR Protocols: A Guide to Methods and Applications. M. A. Innis, D. H. Gelfand, J. J. Sninsky, and T. J. White, eds. Academic Press, San Diego.

52. Yang, W. Q., Harpole, J., Finn, C. E., and Strik, B. C. 2009. Evaluating berry firmness and total soluble solids of newly released highbush blueberry cultivars. Acta Hortic. 810:863-868

53. Yu, P., Li, C., Takeda, F., and Krewer, G. 2012. Visual bruise assessment and analysis of mechanical impact measurement in southern highbush blueberry. Appl. Eng. Agric. In press.

54. Yu, P., Li, C., Takeda, F., Krewer, G., Rains, G., and Hamrita, T. 2012 Quantitative evaluation of a rotary blueberry mechanical harvester using a miniature instrumented sphere. Comput. Electron. Agric. 88:25-31. 